\title{
LOS SUEÑOS EN LA NOVELA GRIEGA: HELIODORO
}

\author{
Regla Fernández Garrido \\ Universidad de Huelva \\ regla@dfint.uhu.es
}

\section{DREAMS IN ANCIENT GREEK NOVEL: HELIODORUS}

\begin{abstract}
En este trabajo se analizan los sueños proféticos de las Etiópicas de Heliodoro, se explican las claves para su interpretación y se ponen de relieve sus funciones dentro del relato. Las visiones oníricas se abordan también como mecanismo para crear suspense y como medio de manifestación de la voluntad divina que preside todo el relato. Se resaltan asimismo los paralelismos y relaciones con los sueños que aparecen en las restantes novelas griegas de amor y aventuras.
\end{abstract}

Palabras clave: novela griega antigua; Heliodoro; sueños y su interpretación.
In this paper prophetic dreams of Heliodorus' Aethiopica are analysed, their interpretation keys are explained and their functions within the narration are emphasized. These oniric visions are also studied as a device to create suspense and as a means of divine will to rule the story. Finally paralelisms and relationships with the dreams of the other Greek love novels are highlighted.

Keywords: Greek ancient novel; Heliodorus; dreams and their interpretation.

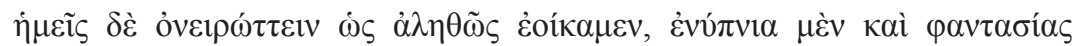

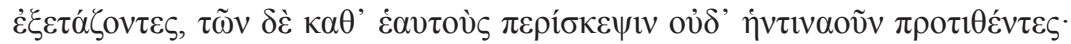
(Hld. II 16.7)

Verdaderamente parece que somos nosotros los que estamos soñando, al investigar sueños y apariciones y no proponer algún tipo de solución a nuestra situación ${ }^{1}$.

Pueden parecer paradójicas estas palabras que Heliodoro pone en boca del ateniense Cnemón a propósito de la interpretación de un sueño de Cariclea, ya que los sueños, entendidos como una forma de manifestación de la voluntad de los dioses, constituyen, junto a otras señales de procedencia divina, un

${ }^{1}$ Todas las traducciones son de la autora del trabajo. 
recurso narrativo muy importante en esta novela. En las páginas que siguen intentaré demostrar la función y la importancia que los sueños tienen en la última de las novelas conservadas. En cuanto a la función, Heliodoro utiliza los sueños como un elemento fundamental para dosificar el suspense y marcar el ritmo de la narración. Por otra parte, las visiones oníricas constituyen una parte importante del sincero ambiente religioso que se respira en toda la novela, junto con otras señales divinas, como los oráculos ${ }^{2}$. Por último, los sueños contienen, asimismo, alusiones y referencias intertextuales a novelas anteriores o a otros géneros, en especial la épica homérica y la tragedia ${ }^{3}$, a los que Heliodoro hace guiños evidentes para el lector culto y con los que demuestra tanto su formación como sus gustos literarios.

Analizaré los sueños de esta novela desde todas estas perspectivas, sin perder tampoco de vista las funciones de los sueños en la novela que he establecido en trabajos anteriores ${ }^{4}$ : función de anticipación de hechos futuros y función de motor, en tanto que las visiones oníricas precipitan y desencadenan — fundamentalmente por las reacciones de los soñadoressucesos que están por venir. Para que el estudio sea completo, me serviré de las claves interpretativas de la obra de Artemidoro de Daldis, que distingue, en la categoría de sueños proféticos ${ }^{5}$, entre alegóricos, directos y oraculares. Los sueños simbólicos o alegóricos significan unas cosas por medio de otras (Artem. I 2, p. 5.9-11 Pack) y deben ser interpretados de acuerdo con las claves conocidas por los tratados de onirocrítica. Los teoremáticos o directos son aquéllos en los que el soñador ve directamente lo

2 Todos estos signos de la voluntad divina son analizados por Saïd en un trabajo que repasa las cinco novelas griegas conservadas completas. En lo que se refiere a Heliodoro, Saïd afirma que es la novela en que los signos divinos tienen más importancia, porque los dioses están por todas partes y manifiestan su voluntad a través de sueños y oráculos, que no siempre son interpretados correctamente, ya que algunos interpretan estas señales en función de sus deseos sin tomarse el intempo de hallar su verdadero sentido (1997, pp. 371-374, 376).

3 Billault 1991, pp. 110-116; Hilton 2001.

${ }^{4}$ Fernández Garrido 2003, pp. 348-349, donde se hace un breve repaso por el estado de la cuestión, al que hay que añadir los trabajos de Liatsi 2004 y Plastira-Valkanou 2001, sobre Jenofonte de Éfeso, y el de Liatsi 2003, sobre la función de los sueños en Aquiles Tacio.

5 'Oveıpos en la terminología de Artemidoro Daldiano, frente al sueño no profético o غ̇vv́tviov, traducido también por 'ensueño' (Artem. I 1, p. 3.9-15 Pack). Puede verse la traslación de los términos en las traducciones de Artemidoro de E. Ruiz 1989 o de M. C. Barrigón y J. M. Nieto 1999, así como el trabajo de estos dos últimos estudiosos de 1992, y Fernández Garrido y Vinagre 2004. 
que va a ocurrir (Artem. I 2, p. 4.22-5.9 Pack). Por último, los oraculares son aquéllos en los que un dios o una persona importante se presenta al soñador y le dirige un mensaje ${ }^{6}$. Al igual que en el resto de los novelistas, Heliodoro no aplica la distinción técnica ente el sueño profético (öveıpos)

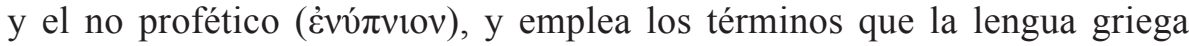

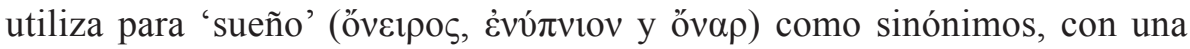
predilección clara por őv $\alpha \rho$, que en ocasiones aparece como entidad acti$\mathrm{va}^{7}$, lo que puede señalarse como una influencia evidente de Homero ${ }^{8}$. Se alude también al sueño fisiológico ( visiones oníricas ${ }^{9}$. El contenido de los sueños se introduce con expresiones como «me pareció ver»o «vi», seguidas de construcción de infinitivo, que es el mecanismo habitual en griego, y es frecuente que se contraponga la visión con la realidad, con la pareja ǒv $\alpha \rho / v \pi \pi \alpha \rho^{10}$.

En Heliodoro aparecen doce sueños proféticos o premonitorios, no todos por supuesto de igual calado para la trama: el sueño del bandido Tíamis (I 18.2-5), el sueño de Cariclea en que le es arrancado el ojo derecho (II 16.1-3), el sueño de Calasiris en que Ártemis y Apolo le confían a los dos jóvenes (III 11.5-12.1), el sueño de Caricles con el águila (IV 14.2), el sueño del rey etíope Hidaspes (IV 8.4), el sueño del campeón tirio (IV 16.7), el sueño de Calasiris con Odiseo (V 22.1-3), los sueños de Ársace (VII 11.1-2), los sueños de Teágenes y Cariclea con Calasiris (VIII 11.1-2 y VIII 11.3-5) y los sueños de los reyes etíopes Hidaspes y Persina (IX 25.1 y X 3.1). Estos doce sueños pueden clasificarse en tres grupos, de cuatro visiones cada uno. El primero, que contiene los cuatro primeros sueños, es el más importante, pues contribuye de manera muy significativa a la intriga y al suspense de la acción. Son, sin duda alguna, las visiones más complejas del relato, aquéllas que, consecuentemente, son descritas con más detalle, y las que necesitan de más fina interpretación. De ellas, tres son simbólicas y una es oracular. El segundo grupo comprende también otros cuatro sueños, con una función

${ }^{6}$ Artemidoro no define los sueños oraculares, pero sí lo hace Macrobio, Somn. I 8.

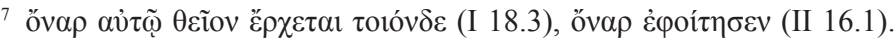

${ }^{8}$ En todos los casos funcionando como sustantivo, excepto en V 22.1, en que aparece como adverbio, el uso extendido en época posthomérica. Sobre la terminología homérica para referirse a los sueños, véase Fernández Garrido y Vinagre 2004, pp. 78-79.

${ }^{9}$ Por ejemplo en I 18.2, II 16.1, V 22.1.

${ }^{10}$ Por ejemplo en II 16.3, III 12.1, VIII 11.1. Para el significado y reparto de estos términos, véase Fernández Garrido y Vinagre 2004, pp. 74-76. 
más o menos literaria o estética ${ }^{11}$, y hacen como de bisagra entre el primer grupo y el tercero. Los últimos cuatro sueños anticipan el final feliz de la historia y el reencuentro de la protagonista con sus padres biológicos y en su tierra nata $1^{12}$. Los sueños se complementan con los dos oráculos que la Pitia de Delfos pronuncia y que se refieren a los tres protagonistas de la novela: Teágenes, Cariclea y Calasiris ${ }^{13}$.

Según la incidencia de la visión en la narración, el autor la describe o se limita a mencionarla sin más. Algunos de estos sueños contienen en su interior oráculos, con lo que entrañan doble complicación: la interpretación del sueño y del críptico mensaje del oráculo. Algunos de estos sueños, como ocurre también con Aquiles Tacio, no se comprenden ni se interpretan correctamente más que cuando se produce su cumplimiento ${ }^{14}$, y ello se debe a la complejidad de los mismos, a las varias interpretaciones de que pueden ser objeto y a que a veces la interpretación que prevalece es la que mejor se adapta a los deseos del soñador y luego resulta ser errónea, como veremos en las páginas que siguen.

Como es bien sabido, esta novela, siguiendo el modelo de la Odisea, empieza in medias res, con la descripción de una escena que no se comprende en todos sus detalles hasta casi la mitad de la obra. Sin duda alguna, la pretensión del autor con este principio impactante e intrigante es mantener el suspense. Desde el comienzo mismo del relato el autor utiliza una técnica de composición basada en dosificar la acción, en informar paulatinamente al lector ${ }^{15}$, ocultando información y engañando tanto a los destinatarios como a los actores de la obra. La intriga es el rasgo fundamental de la primera parte del relato,

${ }^{11}$ Futre Pinheiro (1991, p. 371, n. 25) habla del papel estético-literario de algunos sueños (los de Hidaspes y Persina, la intensificación del pathos dramático producida por los sueños de Cariclea, y la aparición de Odiseo en el sueño de Calasiris), aunque el único sueño en que ambas coincidimos es el de Calasiris con Odiseo.

${ }^{12}$ Me parece interesante la observación de Billault 1991, p. 69, de que las anticipaciones del final feliz del relato casi nunca son comprendidas por los personajes, sólo por el lector.

${ }^{13}$ La relevancia de Calasiris en la novela la adelanta el oráculo que pronuncia la Pitia cuando el anciano entra en el templo de Delfos: el dios reconoce las penas y sinsabores sufridos, le anticipa el regreso a Egipto y lo llama amigo (Hld. II 26.5).

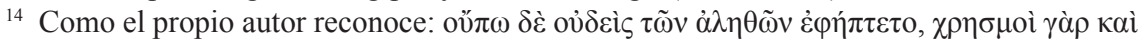

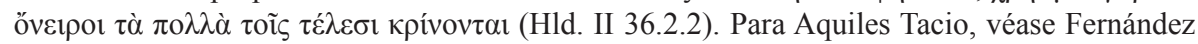
Garrido 2009, pp. 210, 212.

${ }^{15}$ En palabras de Winkler 1982, p. 94: «Heliodoros' principal narrative excellence ... is his disposition of material so as to arouse interest in the careful reader by the giving or withholding of information», y Brioso (1998, p. 132) dice que el lector va sufriendo «aplazamientos». 
con personajes cuya filiación y papel dentro de la narración no comprendemos muy bien, y con aventuras y sucesos que, por no estar cronológicamente ordenados, pueden provocar el desconcierto. Los cuatro primeros sueños contribuyen de manera relevante a crear este ambiente de suspense y sus interpretaciones - verdaderas o erróneas, a propósito o no-, o bien determinan el desarrollo de los hechos futuros cuando provocan una determinada conducta o decisión en el soñador, o bien anticipan hechos que están por venir. En uno y otro caso, el cumplimiento de lo que vaticinan no llega inmediatamente; es más, en consonancia con la expectación que a Heliodoro le gusta crear, no se cumplen hasta bien después de haber sido soñados, y a veces tanto el lector como el soñador corren el peligro de no relacionar la realización con la visión por el tiempo transcurrido. Además, para interpretarlos correctamente hemos de buscar las claves de un sueño en el siguiente.

Sin duda alguna el sueño más complejo es el primero, el sueño del bandido Tíamis (I 18.2-5). Cuando este sueño se produce, suponemos que los protagonistas del relato son Teágenes y Cariclea: no conocemos aún su genealogía, pero por la belleza y otras cualidades que los adornan responden al arquetipo de pareja protagonista. El jefe de los bandidos que los han apresado ha quedado impresionado por la belleza de Cariclea, y sueña con que se halla en Menfis, su ciudad natal, en el templo de la diosa Isis ${ }^{16}$. El templo estaba lleno de víctimas propiciatorias y había un gran tumulto, y en esas circunstancias la diosa se le presenta y le dirige un mensaje directo:

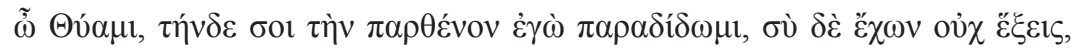

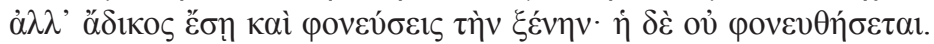

Tíamis, yo te entrego a esta doncella, pero tú, teniéndola, no la tendrás, sino que cometerás una injusticia y matarás a la extranjera, mas ella no será asesinada.

${ }^{16}$ Isis es una diosa de gran relevancia en esta novela: Tíamis es sacerdote de esta diosa, dignidad heredada de su padre Calasiris, por la que pugna con su hermano. Ésta es la diosa que va a proteger a los dos protagonistas a lo largo del relato, con un papel parecido al que tiene Afrodita en Caritón (Ruiz Montero 1989, pp. 125-127) o Eros en Longo (Hunter 1983, pp. 31-36). En la novela de Jenofonte de Éfeso los dioses protectores de los protagonistas son las divinidades locales de los diferentes lugares por donde van pasando (Kytzler 1996, pp. 352-353). Por otra parte, no es extraño que Isis aparezca en relación con los sueños: Isis y Serapis reciben muy a menudo culto conjuntamente y en los serapeos Isis se dedica también a la curación por sueños (Roussel 1916, núms. 64, 169 y 119). 
Estas palabras de la diosa dejan perplejo a Tíamis, que interpreta el sueño de manera simbólica, entendiendo el mensaje divino de acuerdo con sus deseos y considerándolo un buen presagio: la diosa ve con buenos ojos que despose a Cariclea, pues se refiere a ella como mujer que ha superado las «heridas» de la pérdida de la virginidad ${ }^{17}$. En consecuencia, Tíamis pide a sus compinches a la doncella como único botín y renuncia a todo lo demás (I 19.6-7); pretende casarse con ella porque deduce, por sus vestiduras de sacerdotisa de Ártemis, por las riquezas halladas junto a ella, por su propio aspecto y por la entereza con que soporta la desgracia del momento, que desciende de buen linaje y que parece evidente que es la sacerdotisa de algún dios, la pareja ideal para él, sacerdote (I 20). Evidentemente, no puede forzar a la joven a casarse con él, sino que precisa de su consentimiento. Ésta, como parte del engaño y de la dilación, accede a casarse con él, pero le pide que aplace la boda hasta llegar a Menfis (I 22) ${ }^{18}$.

Este sueño presenta paralelos claros con tres sueños de la novela Leucipa y Clitofonte: el primero, el sueño de Clitofonte (IV 1.5-8) en que cree estar en el templo de la diosa Afrodita y ésta le dice que tiene que esperar para unirse sexualmente a Leucipa; el segundo, el primer sueño de Clitofonte (I 3.4-5), también el primero de la novela, en el que se aparece al héroe una mujer terrible que de un tajo y con una guadaña separa a Clitofonte de la doncella a la altura de la cintura; el tercero, el sueño de Pantea, madre de Leucipa, en el que ve que un bandido abre el vientre de Leucipa con una espada y lo interpreta primero en sentido literal (II 23.4-5) e inmediatamente después, a la vista de los acontecimientos, en sentido simbólico (II 24.4) ${ }^{19}$. Tanto en Leucipa y Clitofonte como en Etiópicas, la ambigüedad es buscada intencionadamente por los autores para crear suspense y confusión en los lectores. Todos estos sueños son igualmente turbadores para quienes los tienen y susceptibles de varias interpretaciones. En el caso de Heliodoro, más tarde esta visión de Tíamis recibe una segunda interpretación por parte del bandido, esta vez en sentido literal; en esta ocasión, analiza el sueño no según sus deseos particulares, sino de acuerdo con la situación que está viviendo: entiende que

17 Saïd 1997, p. 376.

${ }^{18}$ En opinión de Bartsch (1989, p. 96) este aplazamiento es bien aceptado por Tíamis porque ve una referencia al sueño que ha tenido y cree que la boda va a tener lugar en Menfis (Hld. II 32.2). Es decir, su error al interpretar el sueño se usa para hacer creíble su paciencia.

19 Véase Fernández Garrido 2009, pp. 209-213, y Liatsi 2003. 
las antorchas y víctimas del templo de Isis representan la sangre y el fuego de la batalla, que el sueño no es simbólico, sino directo, y que le indica que debe matar literalmente a Cariclea, y es lo que hace (o más bien cree hacer) (I 30.4-7). Esta segunda interpretación, en la que el bandido cambia ligeramente el contenido del sueño ${ }^{20}$, no debe resultar convincente para los lectores, quienes, de acuerdo con las convenciones del género, deben saber que la heroína no puede morir, y menos aún al principio del relato. Cualquier lector avispado, por la misma razón, debe también suponer que la mujer a quien mata Tíamis en la cueva no puede ser Cariclea.

Los paralelos entre la visión de Tíamis y las de Aquiles Tacio mencionadas son patentes: el sueño de Tíamis, como el de Clitofonte con Afrodita, es un sueño oracular ( $\chi \rho \eta \mu \alpha \tau 1 \sigma \mu o ́ s)$, que consiste en que una divinidad se presenta a un soñador y le transmite un mensaje en estilo directo: en los dos casos el mensaje está relacionado con el objeto de los amores de los jóvenes. En el sueño de Tíamis, como en el primero de Clitofonte con la mujer de la guadaña, tenemos una palabra que resulta ambigua: en el caso de Aquiles Tacio, el

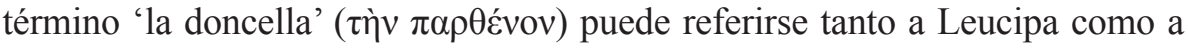

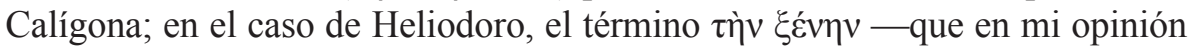
debe traducirse como 'la extranjera' y no como 'la huésped'21 — se refiere tanto a Cariclea como a Tisbe. Cariclea es huésped de Tíamis, no así Tisbe, cuya existencia ni siquiera conoce el bandido. Además, un poco más adelante el propio autor nos da en dos pasajes la clave de esta interpretación: el primero es I 30.7, cuando Tíamis, tras la segunda interpretación del sueño, se dirige a la cueva donde Cariclea - y Tisbe - estaba escondida, para matarla, y mata a la mujer que le contestaba en griego (es evidente que era extranjera). Más tarde, cuando Teágenes descubre que Cariclea está viva y se abraza a ella, Cnemón le reprocha esta conducta licenciosa por «caer abrazado a la extranjera» (II 7.2). Con la expresión 'la doncella', el sueño se refiere a Cariclea ${ }^{22}$,

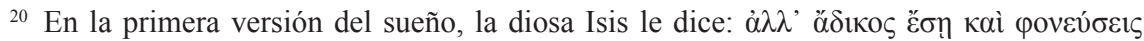

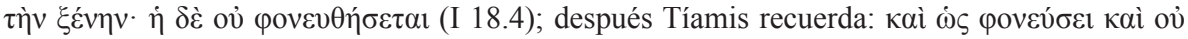
$\tau \rho \omega ́ \sigma \varepsilon \imath$ (I 30.4), Bartsch 1989, p. 97.

${ }^{21}$ Que es como lo interpretan las traducciones al francés y al español de J. Maillon y de E. Crespo, respectivamente. Coincido con Winkler 1982, p. 117, Bartsch 1989, p. 98, y MacAlister 1996, p. 79, que lo traducen como 'foreign woman' y con Saïd 1997, p. 377, que lo entiende como 'l'étrangère'.

${ }^{22}$ No puede referirse a Tisbe pues, por la historia de este personaje, sabemos que no es doncella. 
a quien Isis confía a Tíamis, no para que la despose, sino para que la proteja ${ }^{23}$. Y 'la extranjera' se refiere a Tisbe y a Cariclea: a la primera la asesinará, y a la segunda intentará asesinarla ${ }^{24}$. Las dos interpretaciones que hace Tíamis de su sueño - la primera simbólica, la segunda literal - son paralelas a las dos interpretaciones de Pantea de su visión - la primera simbólica, y la segunda literal - y las conductas que provocan las visiones en los soñadores conducen al cumplimiento de los sueños ${ }^{25}$. Por último, en cuanto a la primera parte del sueño - la llegada de Tíamis al templo de la diosa Isis de Menfis, resplandeciente de antorchas y repleto de público y víctimas propiciatorias - considero que se trata de un sueño teoremático o directo que llega a su cumplimiento seis libros más tarde, cuando Calasiris, devueltos sus honores sacerdotales, los lega a su hijo Tíamis, junto con las obligaciones que tan alta distinción conlleva: proteger a los jóvenes y garantizar su llegada a la patria de Cariclea (VIII 3.7) ${ }^{26}$.

El segundo sueño de este primer bloque es también simbólico, pero de fácil interpretación de acuerdo con los tratados onirocríticos. Cariclea sueña que se le presenta un hombre con un aspecto desaliñado y sucio, con la mano ensangrentada, que le arranca el ojo derecho. Se despierta inmediatamente, sobresaltada, temiendo que el sueño se cumpla en sentido literal (sueño teoremático) pero, al comprobar que aún tenía el ojo, lo interpreta simbólicamente, identificando su ojo derecho con Teágenes ${ }^{27}$, lo más apreciado del mundo. El ateniense Cnemón analiza la visión de acuerdo con los principios onirocríticos: el ojo derecho simboliza al padre ${ }^{28}$, y el sueño significa que su padre ha muerto (Hld. II 16.5-6) ${ }^{29}$.

23 Tíamis recordará más tarde que éste fue el encargo que le dejó su padre, como una de las responsabilidades de la dignidad sacerdotal (VIII 3.7).

24 Bartsch 1989, p. 98, señala que cuando se descubre que la muerta no es Cariclea sino Tisbe es cuando verdaderamente se ha cumplido este sueño.

25 Aunque en el caso de la novela de Aquiles Tacio la muerte de Leucipa resulta ser fingida, mientras que en Heliodoro Tisbe sí que muere de verdad. Si tomamos en consideración tan sólo a las dos heroínas, en los dos casos tendríamos falsas muertes.

26 Coincido con MacAlister 1996, pp. 80-81, n. 26, y Saïd 1997, p. 401.

27 Creo que Futre Pinheiro (1991, p. 367) se equivoca al considerar correcta la interpretación de Cariclea y al considerar que el sueño se cumple cuando Téagenes — que es lo más querido para Cariclea- se separa de ella.

28 Luego Cnemón alude, bromeando, cuando Teágenes y Cariclea están disfrazados de mendigos, a que los dos jóvenes tienen un aspecto desfigurado, sobre todo Cariclea, a la que «le acaban de sacar un ojo» (II 19.1, cf. Kérényi 1973, pp. 51-52).

${ }^{29}$ Artem. I 26 p. 34.7-9 Pack: «el ojo derecho significa el hijo, el hermano y el padre, el izquierdo la hija, la hermana y la madre». Hay que citar también el pasaje anterior, donde se 
Pero, ¿a qué padre se refiere? A estas alturas de la novela, no sabemos quién es el padre de Cariclea, y a lo largo del relato tendremos noticia de que la joven conoce a tres padres: el biológico - Hidaspes - el putativo - Caricles - y el guía espiritual y protector en sus viajes - Calasiris- El sueño alude a Calasiris, a quien después, en otro sueño, los dioses Apolo y Ártemis confían a los jóvenes y cuya relación paternal con éstos es evocada a lo largo del relato ${ }^{30}$. Calasiris morirá más adelante, en VII 11.4, cumpliéndose así el sueño. Entre el sueño y su cumplimiento transcurren cinco libros, la mitad de la novela, lo cual implica la intriga del momento de la visión, cuando no sabemos de quién se está anticipando la muerte, y la necesidad de que el lector, cuando Calasiris muere, recuerde que este suceso ya había sido adelantado. En las expresiones utilizadas para describir el sueño resuenan ecos homéricos: por una parte, el sueño aparece personificado y «visita» al soñador (őv $\alpha \rho \dot{\varepsilon} \varphi o i ́ \tau \eta \sigma \varepsilon v)$ y por otra parte, se contra-

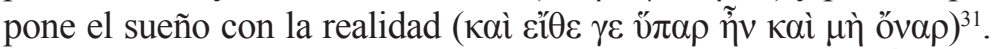

El tercer sueño, el de Calasiris con los dioses Apolo y Ártemis, debe interpretarse en conjunción con el sueño de Cariclea y con los dos oráculos emitidos por la Pitia en el templo de Apolo en Delfos. A Calasiris se le presentan, como si fuera una visión real y no un sueño ${ }^{32}$, los dioses Apolo y Ártemis llevando de la mano — como en el sueño de Tíamis Isis lleva de la mano a Cariclea- a Teágenes y a Cariclea, respectivamente. Es normal que Ártemis lleve a Cariclea de la mano porque ésta es sacerdotisa de la diosa, con la que se confunde por su belleza y atributos, y porque practica los hábitos de vida defendidos por la diosa, sobre todo la virginidad. En cuanto a Teágenes, va naturalmente de la mano de Apolo que es el dios a cuyo templo ha ido en embajada para rendir un sacrificio a Neoptólemo y al final es convertido en sacerdote del dios Sol (Helio $=$ Apolo). Los dos dioses anuncian al anciano

dice que soñar que se está ciego de los dos ojos significa la muerte de los progenitores (junto con la de los hijos o la de los hermanos), ya que «los ojos son la razón de ver la luz, como también los padres» (Artem. I 26, p. 32.20-21 Pack), véase Barstch 1989, p. 99 n. 8, Saïd 1997, p. 100, y Hunter 1998, p. 49.

${ }_{30}$ Winkler 1982, pp. 115-116. En varias ocasiones Calasiris se refiere a los protagonistas como sus hijos, por ejemplo cuando se encuentra con Cnemón en II 23.2, y Cariclea lo invoca como tal cuando muere (VII 14.5).

31 Véase Fernández Garrido y Vinagre 2004, pp. 73-75.

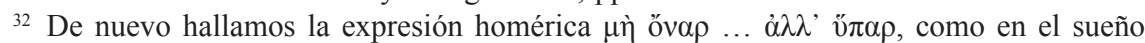
de Cariclea, que también encontraremos cuando Calasiris se presenta a Cariclea en sueños en VIII 11.1. 
sacerdote que es hora de volver a su patria —el sueño de Tíamis también evocaba Menfis ${ }^{33}$ - y que debe llevar consigo a los dos jóvenes protagonistas, a los que debe tratar como hijos ${ }^{34}$. Y anticipan que el final de los protagonistas no es Egipto, sino que Calasiris debe conducirlos más allá — como se verá, será sólo su guía espiritual por medio de los sueños, pues el anciano muere en Menfis- «donde y como los dioses quieran», sin especificar cuál será su destino final. En este sueño también hallamos elementos que aparecen en los dos oráculos de la novela: al llegar a Delfos, la Pitia recibe a Calasiris como su amigo, y le anuncia su vuelta a Egipto (II 26.5), y cuando los dos jóvenes participan en la procesión de Delfos, se oye de fondo a la Pitia, refiriéndose a ellos por la simbología de sus nombres y anunciándoles que abandonarán Delfos, viajarán por mar y llegarán «a la tierra oscurecida del sol, donde alcanzarán un gran premio por sus rectas vidas, blanca corona sobre sus negras

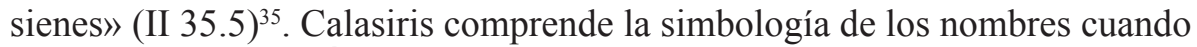
Cariclea, vestida de Ártemis en la procesión, entrega a Teágenes la tea encendida (III 5.7), si bien no acierta a comprender el sentido de la profecía hasta que lee la banda con que Cariclea fue expuesta (IV 9.1).

El cuarto sueño - último de este primer bloque- es el de Caricles con el águila (III 18.1-2) $)^{36}$, que Calasiris interpreta según le conviene en las circunstancias presentes, engañando a propósito al sacerdote de Apolo, y que contiene alusiones a otros sueños y portentos literarios ${ }^{37}$. Para una correcta interpretación de este sueño no deben perderse de vista el sueño anterior de Calasiris y el mensaje del oráculo. Caricles sueña que un águila escapa de la

${ }^{33}$ Aquí se reencontrará Calasiris con sus dos hijos, por lo que los dos sueños anticipan la llegada a esta ciudad. Menfis es una ciudad también vinculada al sueño y en ella existió un importante templo incubatorio de Asclepio-Imouthes (Bouché-Leclerq 1879, vol. III, pp. 377-378).

${ }^{34}$ Debe relacionarse con el sueño de Cariclea de la pérdida del ojo derecho, y con las ocasiones en que Calasiris y Cariclea se presentan como padre e hija y se dan mutuamente este tratamiento (IV 18.1, IV 18.4, V 11.2, V 11.3, V 12.2, V 16.2, V 18.7 o V 19.3).

${ }^{35}$ Los dos oráculos están compuestos en un tono ceremonioso y en dísticos elegíacos, y el segundo está rematado por un quiasmo. En este oráculo ya se anticipa el final del relato, así como en el episodio del soldado muerto al que su madre revive (VI 15.4). Sobre las varias interpretaciones del oráculo y su anticipación de los hechos futuros, véase Hidalgo 1988, p. 181, y Morgan 1989, pp. 307, 318.

${ }^{36}$ Con anterioridad a este pasaje Heliodoro menciona que Caricles ha tenido unos sueños inquietantes (III 18.1 y 2).

${ }^{37}$ Hilton 2001 señala los paralelos con el sueño de Penélope con las ocas de Od. XIX 535-69 y el portento del águila de Ach. Tat. II 12.1-3. 
mano de Apolo, desciende rápidamente, arrebata a su hija de su regazo y se la lleva al último extremo de la tierra, a un lugar sombrío y tenebroso. Caricles está angustiado porque identifica esta tierra con el Hades, por lo que el sueño presagia de manera simbólica la inminente muerte de su hija. Pero Calasiris, y en la misma línea el lector, que tiene más información que Caricles, pone enseguida esta visión en relación con sueños y portentos anteriores y adivina su verdadero significado. No obstante, y para evitar que sus planes se vayan al traste por la intervención de Caricles, decide engañar al sacerdote de Delfos ${ }^{38}$. El águila, le dice Calasiris a Caricles, es el futuro marido ${ }^{39}$ que parte de Apolo porque este dios da su beneplácito a la unión. Ahora bien, la interpretación de Calasiris no dice nada del remoto lugar donde se dirige Cariclea. Parece que esta interpretación contenta a Caricles, que baja un poco la guardia y así se vuelve posible el rapto de Cariclea ${ }^{40}$, el hecho que en verdad anticipa el sueño. El águila es Teágenes, cuya belleza y porte - de los que ha hecho gala en las ceremonias del templo - lo hacen comparable a la reina de las aves; parte de Apolo porque, en efecto, este dios ampara y protege la huida de los jóvenes; y señala también el sueño el destino final: los confines de la tierra deben identificarse con «la tierra oscurecida por el sol» del oráculo, Etiopía. Por lo tanto, el sueño es simbólico en su primera parte - pues el águila simboliza a Teágenes_-, pero directo en su segunda parte — pues el verdadero destino de los jóvenes es el lejano país de Etiopía-.

Sin duda alguna, éstos son los sueños más importantes del relato, tanto por su complejidad como por su incidencia en la trama (como motor de la acción y como anticipación de sucesos por acaecer). Por eso también se encuentran en el primer tercio del relato, cuando el suspense es mayor y los lectores desconocen aún qué ha pasado y cuál es el verdadero origen y destino de algunos protagonistas. $\mathrm{Y}$, aunque de acuerdo con las convenciones novelescas los lectores deben esperar un final feliz, Heliodoro, con sus aplazamientos,

${ }^{38}$ A pesar de que antes Calasiris ha afirmado que intenta ganarse la confianza de Caricles diciéndole sólo la verdad (III 6.4), no sólo lo engaña con esta interpretación, sino que un poco antes le dice que Cariclea sufre un mal de ojo, cuando sabe a ciencia cierta que lo que la joven padece son signa amoris evidentes (III 7.1-2).

${ }^{39}$ Caricles ha decidido casar a su hija con su sobrino, a lo que Cariclea ha accedido para ocultar sus verdaderos planes. Sin duda en este pasaje se evoca el sueño de Penélope con el águila y las ocas, y la interpretación que de él hace el mendigo Odiseo. Véase Hilton 2001, pp. 81-86.

${ }^{40}$ Bartsch 1989, p. 104. De hecho, como señala Saïd 1997, p. 399, se repite el verbo

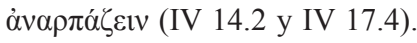


anticipaciones, verdades a medias y dosificación de la información, juega constantemente con el lector, utilizando además para ello a Calasiris ${ }^{41}$.

Los cuatro sueños siguientes pueden incluirse en un segundo bloque cuya función es muy secundaria: actúan como bisagra entre la primera parte del relato y el desenlace del mismo, que comienza a vislumbrarse en el libro octavo. Así, se alude de manera tangencial y sin entrar en detalles a un sueño que tuvo el rey etíope Hidaspes y que le ordenaba unirse a su mujer (IV 8.4) - un sueño oracular, suponemos-. El rey obedece la orden y se produce la concepción de Cariclea, hecho que puede considerarse el primer eslabón del plan divino que gobierna toda la novela. Como intervención divina - aunque no se califica así explícitamente- puede considerarse la rápida alusión al sueño de un joven tirio en el que se le vaticina la victoria en los juegos píticos (IV 16.7). El joven, que viajaba en un barco de mercancías fenicio, decide desviarse de su ruta comercial y hacer una parada en Delfos y efectivamente resulta vencedor en los juegos. Calasiris, cuando planea el secuestro de Cariclea, se encuentra con estos mercaderes mientras están haciendo sacrificios por la victoria, y son éstos quienes proporcionan a Calasiris y a los dos jóvenes el medio para escapar de Delfos. Se cuenta también que la malvada Ársace está siendo perturbada por unos sueños que pretende apaciguar con sacrificios apotropaicos, en claro paralelismo con los sueños que no dejan vivir a Clitemestra (A., Ch. 32-41). El último sueño de este bloque merece algún comentario más, no porque sea un sueño que influya en el desarrollo de la acción, sino porque es un homenaje explícito de Heliodoro al protagonista de la obra que tiene como referente. Me refiero al sueño de Calasiris con Odiseo (V 22.1-3), cuando al sacerdote de Isis se le presenta un anciano que aún conservaba huellas de la fuerza de su juventud, con una mirada inteligente y astuta $^{42}$, que reprocha a Calasiris no haberle demostrado el respeto y la consideración debidos, y que como castigo le augura sufrimientos y dificultades por tierra y $\operatorname{mar}^{43}$. También le transmite para Cariclea saludos de parte de su esposa, quien la tiene en muy buena consideración por su templanza.

${ }^{41}$ Sobre esta cuestión, véase el magnífico trabajo de Winkler 1982.

${ }^{42}$ По $\lambda \dot{\tau} \tau \rho о \pi o v$, epíteto aplicado por antonomasia a Odiseo. Crespo, en nota a la traducción, señala que estas palabras se corresponden con descripción tradicional de Ulises, derivada de Il. XIX 47 ss., Od. XVIII 74 y Od. XIII 332.

${ }^{43}$ Bartsch 1989, p. 101, opina que Odiseo se refiere a la tormenta que va a sufrir Calasiris (V 22.7), aunque reconoce que se trata de un sueño muy vago. Weinstock 1934, p. 50, cita el paralelo con un pasaje de Zósimo (Nueva Historia IV 18.2). En la misma línea, Saïd 
El tercer y último bloque está constituido por cuatro sueños, paralelos dos a $\operatorname{dos}^{44}$. Los sueños de Cariclea y Teágenes con Calasiris pueden considerarse como oraculares, porque Calasiris, una vez fallecido, ha adquirido el estatuto

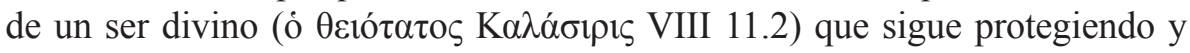
guiando a los dos jóvenes hasta la meta de su viaje. Tras sobrevivir milagrosamente a la condena de ser quemada viva (VIII 9.13-15) ${ }^{45}$, Cariclea recuerda ${ }^{46}$ un sueño que ha tenido con Calasiris en el que el anciano, en dísticos elegíacos, profetiza a la joven que el poder de la «pantarba» ${ }^{47}$ la protegerá del fuego. A posteriori, pues, la muchacha se da cuenta de que su salvación ha estribado en el poder de esta piedra que, junto con las demás joyas con que fue expuesta, la ha acompañado siempre (VIII 11.8). Al oír estas palabras, Teágenes recuerda también otro sueño que ha tenido con Calasiris, en el que éste (VIII 11.3-5) le pronosticaba en dísticos lo siguiente: «Llegarás a la tierra de los etíopes junto a la muchacha, tras huir mañana de las cadenas de Ársace». Teágenes interpreta este vaticinio como un símbolo: el país de los etíopes se refiere al mundo subterráneo, la muchacha a Perséfone, llamada también Core, y la liberación de las cadenas a la separación del alma y el cuerpo. Teágenes entiende que están ante una paradoja: si los destinos de ambos están unidos, ¿cómo puede ser que a Cariclea Calasiris le anuncie un favorable presagio - aunque subsiste la aparente contradicción de que la pantarba ('miedo de todo') pueda precisamente tener el efecto contrario-, mientras que a Teágenes parezca anunciarle la muerte? Cariclea explica a su amado que sus pesimistas interpretaciones responden al estado de ánimo que lo embarga (VIII 11.5) ${ }^{48}$, y que los

1997, p. 399, señala que el sueño se cumple cuando el anciano Calasiris y los jóvenes sufren terribles tempestades (V 22.7 y 27.1-7) y son abordados por piratas (V 24.1-25.3) y atacados, una vez en tierra, por bandidos egipcios (V 33.2).

${ }^{44}$ Sueños que Brioso 1998, p. 139, señala como muestras de los paralelismos que usa Heliodoro.

${ }^{45}$ Comparable a la milagrosa salvación de Habrócomes de la muerte por la intervención del río Nilo, X. Eph. IV 2.4-9: véase Weinstock 1934, p. 47.

${ }^{46}$ Es la primera vez en la novela que no se menciona el sueño inmediatamente después de que ocurra. Se ha olvidado por un momento y se recuerda al día siguiente.

${ }^{47}$ Las propiedades mágicas de la pantarba han sido enumeradas en IV 8.7 y Cariclea las recuerda en VIII 11.8. Crespo (nota ad locum) subraya que el contenido del pentámetro de este oráculo es semejante al de los versos que cierran varias tragedias de Eurípides (Alcestis, Bacantes, Medea, Andrómaca y Helena). Véase Hidalgo 1988, pp. 179-180.

${ }^{48}$ Un estado de ánimo desesperanzado influye tanto en los sueños que se pueden tener como en su interpretación (cf. Liatsi 2004, p. 163, con citas de Artemidoro). 
dos sueños-oráculos deben ser interpretados en sentido literal, no simbólico: los dos se librarán del castigo de Ársace y llegarán juntos (pues «la muchacha» se refiere a ella) a la tierra de los etíopes, que es precisamente la patria de Cariclea y la meta de su viaje (VIII 11.5) ${ }^{49}$. Estos dos sueños presentan claros paralelos con los sueños de Leucipa y Clitofonte de Ach. Tat. IV 1.48, cuando Ártemis y Afrodita, respectivamente, se presentan ante los jóvenes y les transmiten un mensaje de esperanza que les garantiza un final feliz y que los reconforta. También puede resaltarse el paralelismo que tienen con el sueño de Habrócomes con su padre Licomedes en la novela de Jenofonte de Éfeso (II 8.2) que anticipa la reunión final de los jóvenes ${ }^{50}$.

Los dos últimos sueños del relato son los de los reyes etíopes Hidaspes y Persina, personajes que se mencionan por primera vez en la novela en II 24.3, cuando Calasiris dice a Cnemón que Nausicles había planeado enviar a Tisbe como regalo a los reyes etíopes. Estos dos sueños anticipan el inminente reencuentro entre padres e hija y, aunque este reencuentro es buscado por Cariclea, los reyes etíopes no saben que su hija está viva y menos aún tan cerca de ellos. Así, cuando Hidaspes ve por primera vez a los dos jóvenes, ya cautivos de los etíopes, Heliodoro dice que, aunque no sabía aún quiénes eran, «su corazón presentía algo» (IX 1.3), aunque parece que no quería protegerlos, pues tomó la decisión de sacrificarlos a los dioses como primicias de la guerra. Cuando más tarde tiene la oportunidad de verlos más de cerca, el rey recuerda, conmovido, un sueño que ha tenido: le había nacido en ese día una hija con el aspecto y la edad de la muchacha que tenía delante; no le había prestado atención a la visión pero ahora, al ver a la joven, se le había venido a la cabeza (IX 25.1). Los presentes quitan importancia al sueño, considerándolo un efecto de la imaginación que a veces anticipa hechos futuros, pero sin que intervenga para nada la voluntad divina. Hidaspes hace caso y no vuelve a pensar en esta visión. Es más, le presta tan poca atención que incluso llega a bromear cuando contempla al bello Teágenes y cuando Cariclea le dice que sus padres estarán presentes en el sacrificio a que está destinada

49 De hecho, cuando ven llegar a los etíopes, los dos jóvenes no intentan huir para que por fin sean conducidos a Etiopía, como fija su destino (VIII 16.7).

50 Weinstock 1934, p. 47, Fernández Garrido 2003, pp. 362-363. El sueño de Jenofonte de Éfeso, al igual que este sueño de Heliodoro, tiene como función dar ánimos a los soñadores y anticipar hechos futuros, marcando, de manera figurada y simbólica, el rumbo que va a tomar la acción y que va a conducir al final feliz de todos esperado (Plastira-Valkanou 2001, pp. 141-143, y Liatsi 2004, pp. 163, 169). 
(IX 25.3-4). No tiene que resultarnos sorprendente la poca importancia que atribuye el rey a estos sueños, ya que él no tiene ni la más remota idea de que tiene una hija. Creo que puede hallarse una alusión al sueño de Megacles al final de Dafnis y Cloe, cuando el padre biológico de Cloe considera como una burla de los dioses los sueños que tiene en los que una oveja lo hará padre ${ }^{51}$. En uno y otro caso estas visiones están anticipando el reencuentro entre el padre y la hija, aunque los padres no sepan que sus hijas están vivas, y por eso reaccionan así ante estas visiones, sin otorgarles ninguna credibilidad. El último sueño es el de Persina, la reina de Etiopía, quien cuando recibe una carta de su marido comunicándole la victoria sobre los persas y los sacrificios y ceremonias que se van a realizar en agradecimiento a los dioses patrios, recuerda un sueño que acaba de tener y en que le pareció que estaba embarazada y enseguida daba a luz a una niña que al momento se convertía en una joven en edad de casarse (X 3.1). La reina interpreta el sueño en sentido

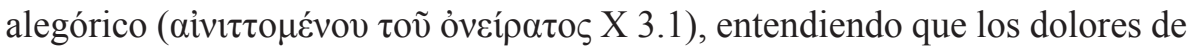
parto simbolizaban las dificultades de la guerra, y la hija la victoria ${ }^{52}$. Pero se equivoca, y el sueño debe ser entendido, como el anterior de Hidaspes, como directo, ya que está anticipando el inminente reencuentro con su hija ${ }^{53}$, además de predisponer favorablemente a los reyes para aceptar más tarde las pruebas que aporta Cariclea sobre su nacimiento y filiación ${ }^{54}$. Este reencuentro y final feliz, no sin algún alboroto y contratiempo en el momento del reconocimiento de Cariclea, es pronosticado también por Sisimitres, el jefe de los gimnosofistas (X 4.2).

Estos últimos cuatro sueños, a diferencia de los cuatro primeros, no encierran ningún misterio para los lectores, no contribuyen a crear suspense ni sorpresa. A medida que la trama de la novela se va desenmarañando y que la información que proporciona Heliodoro a los lectores va cubriendo todas las expectativas de éstos y dejando pocos cabos sueltos, y el final feliz se va

${ }^{51}$ Longus IV 35.5, cf. Fernández Garrido 2004, pp. 351-352.

${ }_{52}$ Esta interpretación sólo se corresponde parcialmente con lo que puede hallarse en Artemidoro: el embarazo, cuando se es rica, es sinónimo de dificultades y preocupaciones (Artem. I 14, p. 22.21 Pack), y el nacimiento de una joven es signo de mal augurio (Artem. IV 10, p. 250.5-6 Pack).

${ }_{53}$ MacAlister 1996, p. 82.

${ }_{54}$ Bartsch 1989, p. 106. De hecho, cuando Persina ve a Cariclea y se entera del destino que su marido ha decidido para ella, recuerda en voz alta a la hija que perdieron y que, de haber vivido, tendría la edad de la joven (X 7.4). 
vislumbrando, los sueños encierran menos secretos, son menos turbadores y más fáciles de interpretar ${ }^{55}$. No obstante, me parece muy interesante resaltar las observaciones de Morgan: «the most characteristic quality of the plotting towards the end of the Aithiopika is its scrupulous unpredictability» (1989, p. 318) e «in short, Heliodoros avoids the closure of his plot until the last possible moment» (1989, p. 319). En efecto, al final de la novela, cuando las reglas del género obligan a que los obstáculos sean vencidos y que los enamorados puedan disfrutar de su amor, Heliodoro sigue sorprendiendo al lector, planteando impedimentos y retrasando el final feliz: la reticencia de Hidaspes a reconocer a Cariclea como hija (X 12.2-3, 13.4-5, 14.3), su determinación a sacrificarla aun sabiendo que es su hija (X 16.4-10), su deseo de que se case con Meroebo (X 24.1), el episodio de Teágenes y el toro (X 28.4-30.7), el enfrentamiento de Teágenes con el gigante de Meroebo (X 31.3-32.2), la aparición de Caricles acusando a Teágenes del rapto de Cariclea (X 32.2) ${ }^{56}$. Tras estos últimos aplazamientos, Hidaspes acepta la propuesta de Sisimitres de sustituir los sacrificios humanos por otros no cruentos, a la vista de que los últimos acontecimientos han sido muestra de la voluntad divina (X 39), y une a los dos jóvenes en matrimonio, a la vez que los consagra como sacerdotes del Sol y la Luna, coronándolos con mitras en una ceremonia que Caricles recuerda que había anticipado la Pitia en Delfos cuando los dos jóvenes se vieron por primera vez (X 40-41). Cf. supra p. 240.

Como recapitulación, y a partir de las consideraciones de este análisis, puede afirmarse que Heliodoro utiliza los sueños en su relato con las mismas funciones que los novelistas anteriores: función de anticipación - para adelantar sucesos que están por venir - y función de motor — cuando desencadenan en el soñador una conducta o reacción que hace avanzar la acción y que al final lleva al cumplimiento real de la visión-. Además de estas dos funciones, Heliodoro utiliza los sueños de forma más compleja y elaborada que sus predecesores, y los pone al servicio tanto de su técnica narrativa como de la voluntad divina que preside la acción. De este modo, los sueños

${ }_{55}$ En palabras de Bartsch 1989, p. 107: «This is not to say that they [i.e. the readers] are becoming cleverer, for they are not. Their knowledge has been gained by the simple act of reading the novel to this point. Furthermore, they see because the author wishes them to see. The transformation from opacity to clarity is deliberate and part of a larger stratagem of the author».

${ }_{56}$ Morgan 1989, pp. 312-318. Sobre el valor religioso de estos episodios, véase Edsall 2000-2001, pp. 125-127. 
se utilizan como mecanismo para dosificar la información y crear suspense - por ello los más difíciles de interpretar se encuentran en la primera parte-, a la vez que manifiestan la voluntad divina $y$, en consecuencia, son apreciados y obedecidos por los personajes. Por último, los sueños contienen alusiones a sueños de novelas anteriores, con claros paralelismos, y de otros géneros literarios, en especial la épica homérica y la tragedia.

\section{BibLIOGRAFÍA}

Artemidoro de Daldis. El libro de la interpretación de los sueños. Traducción de M. C. Barrigón y J. M. Nieto, Madrid, Akal, 1999.

Artemidoro de Éfeso. La interpretación de los sueños. Traducción de E. Ruiz, Madrid, Gredos, 1989.

Heliodoro. Las Etiópicas o Teágenes y Cariclea. Traducción de E. Crespo, Madrid, Gredos, 1979.

Héliodore. Les Éthiopiques. Texte établi par R. M. Rattenbury-T. W. Lumb et traduit par J. Maillon, París, Les Belles Lettres, 1994.

Barrigón, M. C. y Nieto, J. M. 1992: «Algunos problemas de la traducción de la terminología onírica griega al castellano», Epos 8, pp. 465-472.

Bartsch, S. 1989: Decoding the Ancient Novel: The Reader and the Role of Description in Heliodorus and Achilles Tatius, Princeton, Princeton University Press.

Billault, A. 1991: La création romanesque dans la littérature grecque à l'époque impériale, París, Presses Universitaires de France.

Bouché-Leclerq, A. 1880: Histoire de la divination dans l'Antiquité, 4 vols., París (reimpresión Darmstadt, Scientia, 1978).

Brioso, M. 1998: «Aspectos formales del relato en la novela griega antigua», en Brioso, M. y González Ponce, F. J. (eds.), Actitudes literarias en la Grecia romana, Sevilla, Pórtico, pp. 123-208.

Edsall, M. 2000-2001: «Religious Narratives and Religious Themes in the Novels of Achilles Tatius and Heliodorus», Ancient Narrative 1, pp. 114-133.

Fernández Garrido, R. 2003: «Los sueños en la novela griega: Caritón de Afrodisias y Jenofonte de Éfeso», Habis 34, pp. 345-364.

— 2004: «Los sueños en la novela griega: Longo», Habis 35, pp. 343-353.

- 2009: «Los sueños en la novela griega: Aquiles Tacio», Habis 40, pp. 205-214.

— y Vinagre, M. A. 2004: «La terminología griega para 'sueño' y ‘soñar'», CFC:egi 13, pp. 69-104.

Futre Pinheiro, M. P. 1991: «Fonctions du surnaturel dans les Éthiopiques d'Héliodore», Bulletin de l'Association Guillaume Budé, pp. 359-381. 
Hidalgo, M. J. 1988: «Los misterios y la magia en las Etiópicas de Heliodoro», Studia Historica. Historia Antigua 6, pp. 175-188.

Hilton, J. 2001: «The Dream of Charikles (4.14.2): Intertextuality and Irony in the Ethiopian Story of Heliodorus», Acta Classica 44, pp. 77-86.

Hunter, R. L. 1983: A Study of Daphnis \& Chloe, Cambridge, Cambridge University Press.

- 1998: «The Aithiopika of Heliodorus: beyond interpretation?», en Hunter, R. L. (ed.), Studies in Heliodorus, Cambridge, Cambridge Philological Society, pp. $40-59$.

Kérenyi, K. 1973: Die griechisch-orientalische Romanliteratur in Religions-geschichtlicher Beleuchtung, Darmstadt, Wissenschaftliche Buchgesellschaft.

Kytzler, B. 1996: «Xenophon of Ephesus», en Schmeling, G. (ed.), The Novel in the Ancient World, Leiden-Nueva York-Colonia, Brill, pp. 336-359.

Liatsi, M. 2003: «Zur Theorie der Traumfunktion bei Achileus Tatios (Leukippe und Kleitophon I 3.2-3», Hermes 131, 3, pp. 372-379.

- 2004: «Die Träume des Habrokomes bei Xenophon von Ephesos», Rheinisches Museum 147, 2, pp. 151-171.

MacAlister, S. 1996: Dreams and Suicides. The Greek Novel from Antiquity to the Byzantine Empire, Londres-Nueva York, Routledge.

Morgan, J. R. 1989: «A Sense of Ending: The Conclusion of Heliodoros' Aithiopika», Transactions of the American Philological Association 119, pp. 299-320.

Plastira-Valkanou, M. 2001: «Dreams in Xenophon Ephesius», Symbolae Osloenses 76, pp. 137-149.

Roussel, P. 1916: Les cultes égyptiens à Délos du IIIe au Ier siècle av. J.-C., Nancy.

Ruiz Montero, C. 1989: «Caritón de Afrodisias y el mundo real», en Furiani, P. L. y Scarcella, A. M. (eds.), Piccolo Mondo Antico, Perugia, Università degli Studi de Perugia, pp. 107-149.

Saïd, S. 1997: «Oracles et devins dans le roman grec», en Heintz, J. G. (ed.), Oracles et prophéties dans l'Antiquité, París, De Boccard, pp. 367-403.

Weinstock, F. 1934: «De somniorum visionumque in amatoriis graecorum fabulis vi atque usu», Eos 35, pp. 29-72.

Winkler, J. 1982: «The Mendacity of Kalasiris and the Narrative Strategy of Heliodoros’ Aithiopika», Yale Classical Studies 27, pp. 93-158. 